\title{
Determinants of Iron Deficiency and Anemia among Adolescents in a Multi-Cultural Country
}

\author{
Motti Haimi ${ }^{1,2,3 *}$, Galit Goldzak-Kunik ${ }^{1}$, Esther Katz ${ }^{4}$, Torsten Matthias ${ }^{5}$ and Aaron Lerner ${ }^{5}$ \\ ${ }^{1}$ Clalit Health Services, Children's Health Center, Haifa, Israel \\ ${ }^{2}$ Rappaport Faculty of Medicine, Technion, Haifa, Israel \\ ${ }^{3}$ School of Public Health, University of Haifa, Haifa, Israel \\ ${ }^{4}$ Israel's Academic College, Ramat Gan, Israel \\ ${ }^{5}$ Aesku, KIPP Institute, Wendelsheim, Germany
}

\begin{abstract}
Background: Adolescence is a vulnerable period for the development of nutritional anemia

Aim: To evaluate the determinants of iron deficiency, anemia, and associated factors among adolescents who performed routine blood tests in a large district in Israel during 2014.

Methods: A community-based cross-sectional observational study was conducted among adolescents aged 11-18 years, belonging to Haifa and west Galilee district of 'Clalit' Health Services, who routinely performed blood tests during 2014. The blood tests were investigated for iron deficiency (ferritin $<20 \mathrm{ng} / \mathrm{mL}$ ) or anemia (hemoglobin $(\mathrm{HGB})<12 \mathrm{~g} / \mathrm{dl})$.

Results: Among 22310 adolescents who performed blood tests during 2014, 4116 (18.45\%) were found to fulfill the inclusion criteria. $14.8 \%$ were boys, $85.2 \%$ were girls. $2964(13.2 \%)$ adolescents were anemic, with $\mathrm{HGB}<12$ $\mathrm{g} / \mathrm{dl}$, and mean HGB concentration of $11.27 \mathrm{~g} / \mathrm{dl} .1152$ (5.16\%) adolescents had hemoglobin $>12 \mathrm{~g} / \mathrm{dl}$, but ferritin levels $<20 \mathrm{ng} / \mathrm{mL}$, with mean ferritin level of $14.31 \mathrm{ng} / \mathrm{mL}$. Jews significantly had higher mean MCV values, and higher iron levels as compared to non-Jews. The average HGB levels were the lowest in the age groups of 12.515.5 years, and 15.5-17 years. The severity of the anemia correlated significantly with the gender of the adolescent, females having lower HGB concentrations. Ferritin levels correlated significantly with the gender (higher in males), and age of the adolescents (lower at higher ages).
\end{abstract}

Conclusions: Iron deficiency and anemia are common in adolescents, having serious implications. Awareness to this problem should be raised, and decision makers are encouraged to find ways to prevent detect and treat it.

Keywords: Anemia; Iron deficiency; Adolescents; Hemoglobin; Multi-cultural; Israel

\section{Introduction}

Anemia is a condition characterized by reduction in the number of red blood cells and/or hemoglobin (HGB) concentration [1]. Iron deficiency occurs in both developing and developed countries, making it the most common nutritional deficiency worldwide [2]. It is widely accepted that more than a quarter of the world's population lives with iron deficiency [3]. Iron deficiency anemia (IDA) is a common, global public health problem, with major consequences for human health as well as social and economic development [4]. It affects $24.8 \%$ of the world population, with a prevalence of $9 \%$ in toddlers, $9-11 \%$ in adolescent girls, and less than $1 \%$ in teenager boys $[4,5]$.

IDA is most commonly seen in pediatric populations such as in infants fed cow's milk and toddlers fed large volumes of cow's milk [5]. The second peak of IDA seen in teenagers is primarily due to rapid growth and muscle accretion often combined with poor dietary intake of iron. Inadequate diet, medications, low iron availability nutrients, tendency to overweight or obesity, extensive sport, infections, early pregnancy or use of intrauterine devices are some of the risk factors. These contributors may be compounded by menstrual blood loss in adolescent females not receiving supplemental iron $[6,7]$.

The main cause of iron deficiency is a diet that is poor in iron content. For example, to provide the recommended daily intake of iron in adults ( $18 \mathrm{mg}$ per day for young women, $8 \mathrm{mg}$ per day for men and older women), there is a need for about $3,000 \mathrm{kcal}$ of an average Western menu. Iron deficiency anemia is a condition in which anemia occurs due to lack of bioavailable iron to support normal red cell production [8].

Children's food intake habits have changed over the last few decades; children consume too much fat, especially saturated fats, and sweetened beverages. Most school children from low socio-economic families consume too little milk, dairy products and meat. All these factors contribute to the shortage of iron in sufficient quantity in the $\operatorname{diet}[9,10]$.

Adolescence is a vulnerable period in the human life cycle for the development of nutritional anemia [11], and especially iron deficiency and anemia. The prevalence of iron deficiency and subsequent anemia increases at the start of adolescence. In addition to the nutritional deficiencies and increased requirements of nutrition for growth in this period, in girls this is also exacerbated a few years later by the onset of menstruation [12].

Iron is an important component in the formation of $\mathrm{HGB}$, the

*Corresponding author: Motti Haimi, Clalit Health Services, Children's Health Center, Nevieim 18, Haifa, Israel, Tel: +97248351644; Fax: +972722334523; E-mail: morx@netvision.net.il

Received April 22, 2019; Accepted April 30, 2019; Published May 07, 2019

Citation: Haimi M, Goldzak-Kunik G, Katz E, Matthias T, Lerner A (2019) Determinants of Iron Deficiency and Anemia among Adolescents in a Multi-Cultural Country. J Blood Lymph 9: 242. doi: 10.4172/2165-7831.1000242

Copyright: $\odot 2019$ Haimi M, et al. This is an open-access article distributed unde the terms of the Creative Commons Attribution License, which permits unrestricted use, distribution, and reproduction in any medium, provided the original author and source are credited. 
protein found in red blood cells necessary for oxygen transport. Anemia develops as iron stores are depleted, but sometimes iron stores may be depleted, without the patient presenting with an anemia, a situation consistent with iron deficiency. Because of this, HGB alone is not an accurate indicator of iron deficiency anemia [6]. For many years, anemia has been known to impair physical and mental functioning $[13,14]$. In addition, anemia has a negative effect on cognitive performance in adolescents [15].

In recent years, a great deal of information has been accumulated regarding iron deficiency without anemia, which emphasizes the need for measurement of iron level markers in the body and the fact that it is not possible to rely solely on HGB concentration as a measure of iron reserves [3]. Iron deficiency without anemia was much less studied, but in this case, mental impairment and increased fatigue were found, and improved after adequate iron supplements ingestion. The estimated mechanism is a reduction in the availability of iron to various brain enzymes and metabolic pathways [16]. In two similar placebocontrolled studies, iron supplementation with iron deficiency without anemia has improved alertness, concentration, mood, and memory ability, without affecting the HGB levels, and only the iron reservoir markers were improved $[17,18]$. Notably, over the last 20 years, there has been a great deal of information about the damage to the maximum physical capacity caused by iron deficiency without anemia. Most of the studies on this subject have been carried out among adults only; few studies were performed in children and youth [19-23].

The present study aimed to evaluate the determinants of anemia, iron deficiency, and associated factors among adolescents who performed routine blood tests in a large Northern district in Israel during 2014. This is the largest analysis done in a multi-cultural country like Israel.

\section{Methods}

The present study was a community-based cross-sectional observational analysis conducted among adolescents aged 11-18 years, belonging to Haifa and west Galilee district of 'Clalit' Health Services, who routinely performed blood tests during 2014.

The inclusion criteria were: adolescents aged 11-18 years, who belong to Haifa and West Galilee district of 'Clalit' Health Services, who performed blood test during the year 2014. The cut-offs were: Haemoglobin $(\mathrm{HGB})<12 \mathrm{~g} / \mathrm{dl}$, or ferritin $<20 \mathrm{ng} / \mathrm{mL}$, thus dividing the participants into 2 groups. The exclusion criteria were: adolescents with chronic intestinal disease like Inflammatory bowel disease (IBD), thalassemia, or those who take medications (antacids, allopurinol, aspirin, steroids, etc.) that may impair the absorption of iron.

For every adolescent included in the study, the records for demographic data (age, gender, place of residence, religion), weight, Body mass index (BMI), presence of other diseases, and smoking were also checked. The records for mean corpuscular volume (MCV), Mean corpuscular hemoglobin $(\mathrm{MCH})$, blood iron level and transferrin were also included, if available.

The severity of anemia in this study was graded, according to the HGB levels, as mild $(>11 \mathrm{~g} / \mathrm{dl})$, moderate $(9-11 \mathrm{~g} / \mathrm{dl})$ and severe $(<9$ $\mathrm{g} / \mathrm{dl}$ ). According to the local laboratory references, microcytosis was defined as a mean corpuscular volume value $<78 \mathrm{fL}$, and hypochromia was defined as $\mathrm{MCH}$ concentration value $<26 \mathrm{~g} / \mathrm{dl}$.

\section{Statistical analysis}

The SPSS 21.0 software was used for data analysis. Fischer's exact test and analysis of variance (ANOVA) were performed. Distributions of HGB values and distributions of ferritin levels, in the different levels, were analyzed using Chi-Squared test (after Bonferroni correction). Pearson's correlation tests were conducted to examine the relationship between adolescent age and blood tests (HGB, RBC (Red blood cells), $\mathrm{MCV}, \mathrm{MCH}$, Ferritin and Iron) and anthropometric measures (height, weight, age).

To examine differences in the indices (HGB, RBC, MCV, MCH, Ferritin and Iron) between the age categories, ANOVA analysis tests and post-hoc Tuckey tests were conducted. $p<0.05$ was considered as significant.

\section{Results}

\section{Participants}

The total population of adolescents aged 11-18 years, belonging to Haifa and West Galilee of Clalit Health Care Services, during 2014, was 78558. 22310 adolescents from this group performed blood tests during this year. Although it was not a random sample, it served us as the sample size. Total number of adolescents who eventually fulfilled the inclusion criteria and included in the study was 4116 (18.45\%).

\section{Demographics and general characteristics}

Among the adolescents included in the study, $14.8 \%$ were boys and 85.2\% were girls. $45.8 \%$ were of Arab origin, $54.2 \%$ were Jews $(0.5 \%$ were orthodox Jews). $41 \%$ were at age $12.5-15.5$ years, and $26.3 \%$ were at age $15.5-17$ years (Table 1 ).

Among the non-Jewish adolescents, most of them are living in Arab cities and villages (93\%); among the Jewish adolescents, half are living in small cities, 25\% are living in large cities and 25\% in small towns, villages and Kibbutzim. 14\% of the adolescents included in the study had obesity, $2.6 \%$ had asthma, $2.1 \%$ had hyperlipidemia, and with lesser degrees smoking (1.7\%), celiac (1.2\%) and diabetes $(0.7 \%)$.

The mean and median ages of participants were close to 15 years. The mean weight was $55.1 \mathrm{~kg}$, mean height was $154 \mathrm{~cm}$, and mean BMI was 21.72 (Table 2a). Several measures were significantly higher among

\begin{tabular}{|l|l|l|}
\hline Factor & Category & $\%(\mathbf{n})$ \\
\hline Gender, $\mathrm{n}=4116$ & Male & $14.8(608)$ \\
\hline \multirow{2}{*}{ Religion, $\mathrm{n}=4101$} & Female & $85.2(3508)$ \\
\hline Age category (years), $\mathrm{n}=4116$ & Jewish & $53.7(2202)$ \\
\hline & Arab & $45.8(1879)$ \\
\hline & Orthodox Jews & $0.5(20)$ \\
\hline & $11-12.5$ & $14.5(596)$ \\
\hline & $12.5-15.5$ & $41.0(1687)$ \\
\hline $15.5-17$ & $26.3(1083)$ \\
\hline & $17-18$ & $18.2(750)$ \\
\hline
\end{tabular}

Table 1: Gender, religion and age distribution of the adolescents.

\begin{tabular}{|l|c|c|c|c|c|c|}
\hline & $\begin{array}{c}\text { Age } \\
\text { (years) }\end{array}$ & $\begin{array}{c}\text { Weight } \\
\mathbf{( K g )}\end{array}$ & $\begin{array}{c}\text { Height } \\
\mathbf{( c m )}\end{array}$ & $\begin{array}{c}\text { BMI Percentile } \\
\text { (BO) }\end{array}$ & $\begin{array}{c}\text { Percentile BMI } \\
\text { (calculated) }\end{array}$ & BMI \\
\hline Mean & 14.8 & 55.1 & 154.03 & 56.63 & 63.79 & 21.72 \\
\hline Median & 15.0 & 53.0 & 159.00 & 59.71 & 75.00 & 20.69 \\
\hline Mode & 16.8 & 50.0 & 160.00 & 99.99 & 75.00 & 19.53 \\
\hline SD & 2.0 & 15.7 & 27.96 & 33.81 & 30.96 & 5.20 \\
\hline Range & 7.0 & 119.0 & 192.91 & 100.00 & 97.00 & 38.48 \\
\hline Min. & 11.0 & 18.0 & 1.09 & 0.00 & 3.00 & 11.90 \\
\hline Max. & 18.0 & 137.0 & 194.00 & 100.00 & 100.00 & 50.38 \\
\hline $\mathrm{n}$ & 4116 & 1809 & 1809 & 1809 & 1809 & 1809 \\
\hline
\end{tabular}


girls as compared to boys: mean age of girls (15.3 years) was higher than the mean age of boys (13.1 years), mean weight of girls $(55.7 \mathrm{~kg}$ ) was higher than mean weight of boys $(51.2 \mathrm{~kg})$, and same for BMI's (Table 2b).

\section{Blood measurements}

Regarding the blood measures of the adolescents, 2964 (13.2\%) adolescents were anemic, with $\mathrm{HGB}<12 \mathrm{~g} / \mathrm{dL}$, thus fulfilling the inclusion criteria. Their mean HGB concentration was $11.27 \mathrm{~g} / \mathrm{dL}$ (SD 0.87). 1152 (5.16\%) adolescents had HGB $>12 \mathrm{~g} / \mathrm{dL}$, but ferritin levels $<20 \mathrm{ng} / \mathrm{mL}$, thus fulfilling the inclusion criteria. Their mean ferritin level was $14.31 \mathrm{ng} / \mathrm{ml}$ (SD 3.49) (Table 3a). Among the 2964 with $\mathrm{HGB}<12 \mathrm{~g} / \mathrm{dL}, 2851$ had additional data concerning the red blood cells; $60.7 \%$ had $\mathrm{RBC}<4.5 \times 10^{6} /$ microliter, $52.7 \%$ had $\mathrm{MCH}<26 \mathrm{~g} / \mathrm{dL}$, and $36.2 \%$ had $\mathrm{MCV}<78 \mathrm{fL}$, thus implying to have iron deficiency anemia (Table 3b).

All blood measures except for MCH (HGB, RBC, MCV, Ferritin and Iron) were significantly $(p<0.001)$ higher among boys as compared

\begin{tabular}{|c|c|c|c|c|c|}
\hline & \multicolumn{2}{|c|}{ Males } & \multicolumn{2}{|c|}{ Females } & \multirow[t]{2}{*}{$t(d f), p$} \\
\hline & Mean & SD & Mean & SD & \\
\hline Age $^{a}$ (years) & 13.1 & 1.6 & 15.3 & 1.8 & $\mathrm{t}(904)=-29.81, p<0.001$ \\
\hline $\mathrm{BMI}^{\mathrm{a}}$ & 20.9 & 5.8 & 21.9 & 5.0 & $\mathrm{t}(379)=-2.89, p<0.01$ \\
\hline Height (cm) & 151.5 & 26.3 & 154.7 & 27.3 & $\mathrm{t}(813)=-1.89, p=0.065$ \\
\hline Weight ${ }^{\mathrm{a}}(\mathrm{kg})$ & 51.2 & 18.6 & 55.7 & 14.3 & $\mathrm{t}(361)=-3.94, p<0.001$ \\
\hline
\end{tabular}

Table 2b: Age and body indices in males and females (using $t$ tests).

\begin{tabular}{|c|c|c|c|c|c|c|}
\hline & HGB & RBC & MCV & $\mathrm{MCH}$ & Ferritin & Iron \\
\hline & g/dl & $\times 10^{6} /$ microliter & $\mathrm{fL}$ & g/dl & $\mathrm{ng} / \mathrm{mL}$ & $\mathrm{mcg} / \mathrm{dL}$ \\
\hline Mean & 11.27 & 4.66 & 79.23 & 25.58 & 14.31 & 62.74 \\
\hline Median & 11.60 & 4.61 & 80.80 & 26.20 & 14.55 & 57.00 \\
\hline Mode & 12.00 & 4.57 & 82.70 & 27.60 & 14.80 & 52.00 \\
\hline SD & 0.87 & 0.54 & 8.52 & 3.29 & 3.49 & 35.39 \\
\hline Range & 7.30 & 7.15 & 118.20 & 38.30 & 14.60 & 247.00 \\
\hline Min. & 4.70 & 0.00 & 0.00 & 0.00 & 5.40 & 0.00 \\
\hline Max. & 12.00 & 7.15 & 118.20 & 38.30 & 20.00 & 247.00 \\
\hline $\mathrm{N}$ & $N=2964$ & $N=4116$ & $N=4116$ & $N=4116$ & $N=1152$ & $N=2450$ \\
\hline
\end{tabular}

Table 3a: Distribution of blood values: $\mathrm{HGB}, \mathrm{RBC}, \mathrm{MCV}, \mathrm{MCH}$, Ferritin and Iron.

\begin{tabular}{|l|l|l|l|l|}
\hline $\begin{array}{l}\text { HGB } \\
\text { criterion } \\
n=2851\end{array}$ & $\mathrm{n}=2632$ & $\begin{array}{l}52.7 \% \mathrm{MCH}<26 \\
36.2 \% \mathrm{MCV}<78 \\
60.7 \% \mathrm{RBC}<4.5\end{array}$ & $\begin{array}{l}(\mathrm{MCV}<78) \text { or }(\mathrm{MCH}<26) \text { or } \\
(\mathrm{RBC}<4.5)\end{array}$ & 1 \\
\cline { 2 - 5 } & $\mathrm{n}=219$ & $60.7 \%$ & $\begin{array}{l}(\mathrm{MCV}<78) \text { and }(\mathrm{MCH}<26) \text { and } \\
(\mathrm{RBC}<4.5)\end{array}$ & 2 \\
\hline $\begin{array}{l}\text { Ferritin } \\
\text { criterion } \\
\mathrm{n}=1152\end{array}$ & $\mathrm{n}=1152$ & $\begin{array}{l}8.1 \% \mathrm{MCH}<26 \\
5.1 \% \mathrm{MCV}<78 \\
25.6 \% \mathrm{RBC}<4.5\end{array}$ & $\begin{array}{l}(\mathrm{MCV}<78) \text { or }(\mathrm{MCH}<26) \text { or } \\
(\mathrm{RBC}<4.5)\end{array}$ & 3 \\
\hline Note: $\mathrm{MCV}$ in fL; $\mathrm{MCH}$ in $\mathrm{g} / \mathrm{dl}$ and $\mathrm{RBC}$ in $\times 10^{6} /$ microliter & \\
\hline
\end{tabular}

Note: $\mathrm{MCV}$ in $\mathrm{fL} ; \mathrm{MCH}$ in $\mathrm{g} / \mathrm{dl}$ and $\mathrm{RBC}$ in $\times 10^{6} /$ microliter

Table 3b: Blood count values according to the different inclusion criteria.

\begin{tabular}{|c|c|c|c|c|c|c|}
\hline & \multirow[t]{2}{*}{ Units } & \multicolumn{2}{|c|}{ Males } & \multicolumn{2}{|c|}{ Females } & \multirow[t]{2}{*}{$t(d f), p$} \\
\hline & & Mean & SD & Mean & SD & \\
\hline $\mathrm{HGB}^{\mathrm{a}}$ & $\mathrm{g} / \mathrm{dl}$ & 11.5 & 0.8 & 11.3 & 0.9 & $t(652)=4.68, p<0.001$ \\
\hline Ferritin & $\mathrm{ng} / \mathrm{mL}$ & 15.3 & 3.3 & 14.1 & 3.5 & $t(1150)=4.43, p<0.001$ \\
\hline $\mathrm{MCH}^{\mathrm{a}}$ & g/dl & 26.2 & 2.9 & 26.4 & 2.8 & $\mathrm{t}(813)=-0.97, p$ value $\mathrm{n} . \mathrm{s}$. \\
\hline MCV & $\mathrm{fL}$ & 80.1 & 8.0 & 81.4 & 7.1 & $\mathrm{t}(1150)=-4.33, p<0.001$ \\
\hline RBC & $\times 10^{6} /$ microliter & 4.5 & 0.5 & 4.5 & 0.4 & $\mathrm{t}(4114)=4.91, p<0.001$ \\
\hline Iron & $\mathrm{mcg} / \mathrm{dL}$ & 65.2 & 34.5 & 60.0 & 34.6 & $\mathrm{t}(2448)=2.66, p<0.01$ \\
\hline
\end{tabular}

Table 4: Differences in blood values among genders, using t-tests (for independent samples).

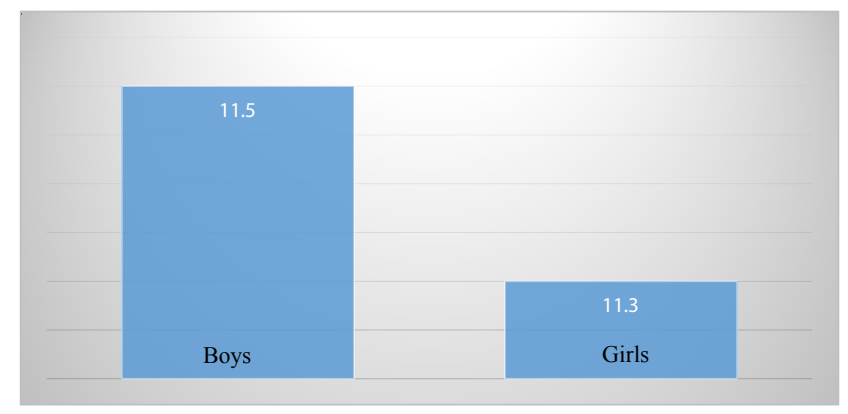

Figure 1: Average HGB levels in boys and girls in $\mathrm{g} / \mathrm{dL}$.

\begin{tabular}{|c|c|c|c|c|c|c|}
\hline & \multirow[t]{2}{*}{ Units } & \multicolumn{2}{|c|}{$\begin{array}{c}\text { Non-Jews } \\
(n=1179)\end{array}$} & \multicolumn{2}{|c|}{$\begin{array}{c}\text { Jews } \\
(n=2202)\end{array}$} & \multirow[t]{2}{*}{$t(d f)$} \\
\hline & & Mean & SD & Mean & SD & \\
\hline HGB & $\mathrm{g} / \mathrm{dl}$ & 11.3 & 0.9 & 11.3 & 0.8 & $-2.053^{*}$ \\
\hline Ferritin & $\mathrm{ng} / \mathrm{mL}$ & 14.2 & 3.5 & 14.3 & 3.5 & -.414 \\
\hline $\mathrm{MCH}$ & $\mathrm{g} / \mathrm{dl}$ & 25.9 & 2.7 & 26.7 & 2.8 & -9.160 \\
\hline MCV & $\mathrm{fL}$ & 80.6 & 7.0 & 81.8 & 7.4 & $-5.230^{* *}$ \\
\hline RBC & $\times 10^{6} /$ microliter & 4.5 & 0.4 & 4.5 & 0.4 & 1.370 \\
\hline Iron & $\mathrm{mcg} / \mathrm{dl}$ & 55.0 & 31.9 & 64.6 & 35.9 & $-6.960^{* *}$ \\
\hline
\end{tabular}

${ }^{*} \mathrm{p}<0.05 ;{ }^{* *} \mathrm{p}<0.01$

Table 5: Differences in blood values among Jews and non-Jews using t-tests (for independent samples)

to girls. Mean HGB level (11.5 g/dl, SD 0.8) was higher among boys as compared to girls $(11.3 \mathrm{~g} / \mathrm{dl}, \mathrm{SD} 0.9)$, with more heterogenic distribution among girls $(p<0.001)$ (Table 4 and Figure 1$)$.

\section{Ethnic differences}

$t$ tests were used to estimate differences of blood values between Jews and non-Jews (Table 5). Significant differences were found regarding $\mathrm{HGB}$ levels, MCV and iron. Although the mean HGB values were similar $(11.3 \mathrm{~g} / \mathrm{dl})$ on both Jews and non-Jews, there was a significant difference $(p<0.01)$ of the variances, while the variance was higher among non-Jews $(\mathrm{SD}=0.9)$ as compared to Jews $(\mathrm{SD}=0.8)$.

There was a significant difference regarding MCV values $(p<0.01)$, with higher mean MCV among Jews (Mean=81.8 $\mathrm{fL}, \mathrm{SD}=7.4$ ) as compared to non-Jews (Mean=80.6 fL, $\mathrm{SD}=7.0$ ). Iron levels were significantly higher $(p<0.01)$ among Jewish adolescents $($ Mean $=64.6$ $\mathrm{mcg} / \mathrm{dL}$ and $\mathrm{SD}=35.9)$ as compared to non-Jewish adolescents (Mean $=55 \mathrm{mcg} / \mathrm{dL}$ and $\mathrm{SD}=31.9$ ) (Table 5 and Figure 2).

\section{Age differences}

The correlation between the ages of the adolescents, and body and blood measurements, was analyzed using Pierson correlation matrix (Table 6). Several significant correlations between age and several factors were observed: negative correlations $(0.055$ to 0.114 $\mathrm{g} / \mathrm{dL}$ ) between age and HGB level, ferritin RBC and iron (higher age correlated with lower levels of these factors); and positive correlations ( 0.050 to 0.274 ) between age and $\mathrm{MCH}, \mathrm{MCV}, \mathrm{BMI}$, height and weight.

When age was divided into 4 age-groups, significant differences were observed in all parameters between the age-groups, including HGB levels (Table 7): the average HGB level declined from $11.4 \mathrm{~g} / \mathrm{dL}$ at the $11-12.5$ years age group, to $11.3 \mathrm{~g} / \mathrm{dL}$ at the $12.5-15.5$ years age group, and then to $11.2 \mathrm{~g} / \mathrm{dL}$ at the $15.5-17$ years age group. At the last age group (17-18 years), the average levels were elevated to $11.3 \mathrm{~g} / \mathrm{dL}$ (Figure 3 ). 
Citation: Haimi M, Goldzak-Kunik G, Katz E, Matthias T, Lerner A (2019) Determinants of Iron Deficiency and Anemia among Adolescents in a MultiCultural Country. J Blood Lymph 9: 242. doi: 10.4172/2165-7831.1000242

Page 4 of 7

\begin{tabular}{|c|c|c|c|c|c|c|c|c|c|}
\hline & HGB & Ferritin & MCH & MCV & RBC & Iron & BMI & Height & Weight \\
\hline $\mathrm{MCH}$ & $0.663^{* *}$ & $0.079^{* *}$ & - & & & & & & \\
\hline CV & $0.590^{* *}$ & $0.063^{*}$ & $0.920^{* *}$ & - & & & & & \\
\hline RBC & $0.146^{* *}$ & 0.014 & $-0.057^{\star *}$ & 0.006 & - & & & & \\
\hline Iron & $0.404^{* *}$ & $0.149^{* *}$ & $0.438^{* *}$ & $0.386^{* *}$ & 0.016 & - & & & \\
\hline BMI & 0.027 & 0.055 & $-0.136^{\star *}$ & $-0.138^{* *}$ & 0.004 & $-0.176^{\star *}$ & - & & \\
\hline Height & 0.033 & -0.033 & 0.025 & 0.020 & -0.018 & 0.015 & 0.009 & - & \\
\hline Weight & 0.019 & 0.043 & $-0.117^{\star *}$ & $-0.111^{* *}$ & -0.008 & $-0.167^{\star *}$ & $0.921^{* *}$ & $0.140^{* *}$ & - \\
\hline Age & $-0.057^{\star *}$ & $-0.114^{\star *}$ & $0.050^{\star *}$ & $0.096^{* *}$ & $-0.111^{\star *}$ & $-0.055^{\star *}$ & $0.138^{\star *}$ & $0.095^{\star *}$ & $0.274^{\star *}$ \\
\hline
\end{tabular}

Table 6: Pearson correlation matrix between the age of the adolescent and blood and body variables.

\begin{tabular}{|c|c|c|c|c|c|c|c|c|c|c|c|}
\hline & \multirow[t]{3}{*}{ Units } & \multicolumn{10}{|c|}{ Age in years $(n)$} \\
\hline & & \multicolumn{2}{|c|}{$11-12.5(n=583)$} & \multicolumn{2}{|c|}{$12.5-15.5(n=771)$} & \multicolumn{2}{|c|}{$15.5-17(n=916)$} & \multicolumn{2}{|c|}{$17-18(n=1833)$} & \multicolumn{2}{|c|}{ Total $(n=4103)$} \\
\hline & & Mean & SD & Mean & SD & Mean & SD & Mean & SD & Mean & SD \\
\hline $\mathrm{HGB}^{* *}$ & $\mathrm{~g} / \mathrm{dl}$ & 11.4 & 0.8 & 11.3 & 0.9 & 11.2 & 0.9 & 11.3 & 0.8 & 11.4 & 0.8 \\
\hline Ferritin** & $\mathrm{ng} / \mathrm{mL}$ & 14.8 & 3.4 & 14.5 & 3.4 & 13.7 & 3.6 & 14.0 & 3.6 & 14.3 & 3.5 \\
\hline $\mathrm{MCH}^{* *}$ & $\mathrm{~g} / \mathrm{dl}$ & 26.1 & 2.6 & 26.3 & 2.8 & 26.4 & 2.8 & 26.5 & 2.9 & 26.3 & 2.8 \\
\hline $\mathrm{MCV}^{* *}$ & $f L$ & 80.0 & 7.0 & 81.0 & 7.3 & 81.6 & 6.9 & 82.0 & 7.2 & 81.2 & 7.2 \\
\hline $\mathrm{RBC}^{* *}$ & $\times 10^{6} /$ microliter & 4.5 & 0.4 & 4.5 & 0.4 & 4.4 & 0.3 & 4.4 & 0.4 & 4.5 & 0.4 \\
\hline Iron* & $\mathrm{mcg} / \mathrm{dl}$ & 64.9 & 34.1 & 60.6 & 32.8 & 61.2 & 36.0 & 58.3 & 36.0 & 60.7 & 34.6 \\
\hline
\end{tabular}

${ }^{*} p<0.05,{ }^{* *} p<0.01$

Table 7: Variance analysis (ANOVA) for differences in blood variables in different age groups.

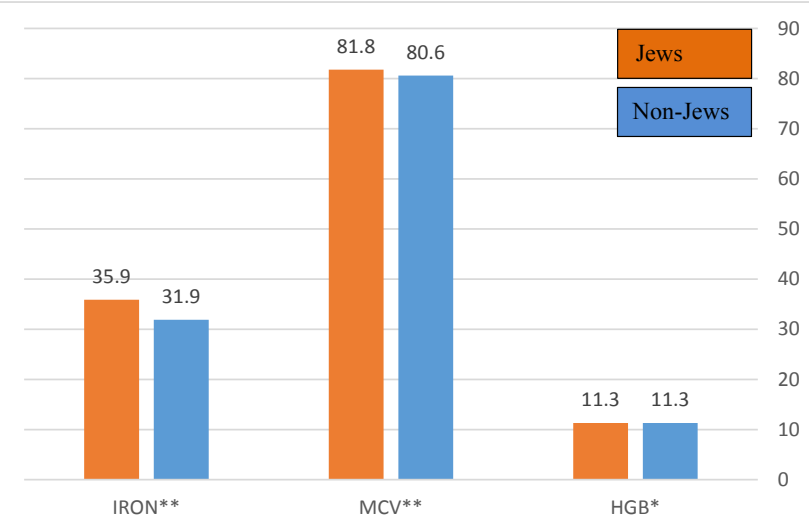

Figure 2: Average values of $\mathrm{HGB}, \mathrm{MCV}$ and iron among Jews and non-Jews. HGB -g/dL, MCV-fL, Iron-mcg/dL.

The post-hoc Tukey's analysis demonstrated that the difference between the HGB levels in the different age groups originated from the difference between the first group (11-12.5 years) and the next two groups (12.5-15.5 and 15.5-17 years). The $2^{\text {nd }}$ and $3^{\text {rd }}$ age groups (12.515.5 and 15.5-17 years) are homogenous regarding the HGB levels (Figure 4).

In order to check the differences in mean HGB values between the different age groups in relation to the gender of the adolescent, 2-dimensional univariate analysis of variance was used. Although the age was found to have a significant effect on HGB levels (F (3, 2956) $=3.766, p=0.01$ and $\eta=0.004)$, the gender was not found to have a significant effect on HGB values $(\mathrm{F}(1,2956)=0.160$ and $p$ value $n . s)$, and the interaction between the age and gender was also not found to be significant, in this analysis (data not shown).

\section{Severity of anemia and iron deficiency}

In order to examine the correlation between HGB values and different parameters, the adolescents' HGB values which were included

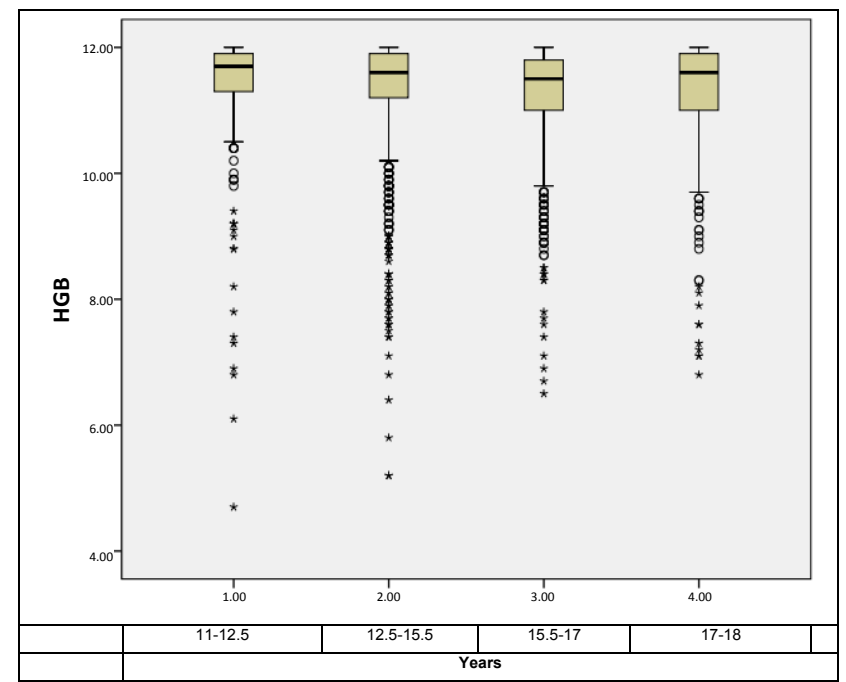

Figure 3: Distribution of HGB's average values in different age groups (Box plot).

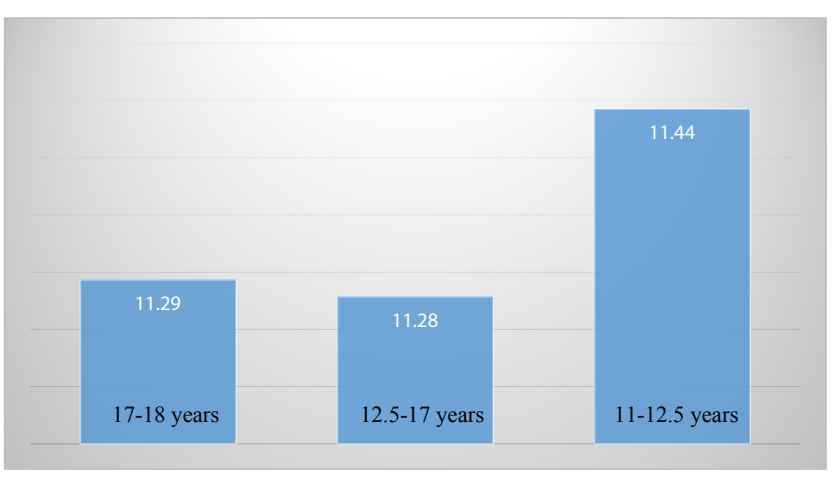

Figure 4: Average HGB levels in different age categories $\mathrm{g} / \mathrm{dL}$. 


\begin{tabular}{|c|c|c|c|c|c|c|}
\hline & & Total & $<9$ & $9-11$ & $>=11$ & $p$ value \\
\hline & & $n=2964$ & $n=93$ & $n=502$ & $n=2369$ & \\
\hline Gender & Male (\%) & $431(14.5)$ & $10(2.3)$ & $41(9.5)$ & $380(88.2)$ & $<0.0001^{\circ}$ \\
\hline & Female (\%) & $2533(85.5)$ & $83(3.3)$ & $461(18.2)$ & 1989 (78.5) & \\
\hline Age, me & & $15.0 \pm 1.97$ & $14.8 \pm 1.8$ & $15.4 \pm 1.8$ & $14.9 \pm 2.0$ & $<0.0001^{a, c}$ \\
\hline Obesity, & & $461(15.6)$ & $15(3.3)$ & $52(11.3)$ & 394 (85.5) & $0.002^{c}$ \\
\hline
\end{tabular}

aSig. difference after Bonferroni correction between level 1 \& level 2; c Sig difference after Bonferroni correction between level 2 \& level 3

Table 8: Correlation between different variables and severity of anemia (only significant result shown).

\begin{tabular}{|c|c|c|c|c|c|c|}
\hline & Total & $<10$ & $10-15$ & $>=15$ & \multirow[t]{2}{*}{$p$ value } \\
\hline & & $n=1152$ & $n=176$ & $n=447$ & $n=529$ & \\
\hline \multirow[t]{2}{*}{ Gender } & Male (\%) & $177(15.4)$ & $11(6.2)$ & $62(35.0)$ & $104(58.8)$ & $<0.0001^{a, b, c}$ \\
\hline & Female (\%) & $975(84.6)$ & $165(16.9)$ & $385(39.5)$ & $425(43.6)$ & \\
\hline \multicolumn{2}{|c|}{ Age, mean $\pm S D$} & $14.8 \pm 1.9$ & $15.2 \pm 1.9$ & $14.9 \pm 1.9$ & $14.6 \pm 2.0$ & $0.002^{b, c}$ \\
\hline
\end{tabular}

a Sig difference after Bonferroni correction between level 1 \& level 2; ' Sig difference after Bonferroni correction between level 1 \& level 3 ; c Sig difference after Bonferroni correction between level 2 \& level 3

Table 9: Correlation between different variables and ferritin levels (only significant result shown).

in the study $(\mathrm{HGB}<12 \mathrm{~g} / \mathrm{dL}(\mathrm{gr} \%))$ were further divided to 3 severity levels: below 9 gr\%, 9-11 gr\% and $\geq 11 \mathrm{~g} / \mathrm{dL}$ gr\%.

Table 8 presents the distribution of HGB values in the different levels (numbers and percentages), using Chi-Squared test (after Bonferroni correction) and ANOVA tests. The gender of the adolescent was found to have a significant correlation with the severity of the anemia $(p<0.001)$; females having lower HGB concentrations. Thus, $88.2 \%$ of the male adolescents had HGB concentrations in the higher level ( $\geq 11$ gr\%), compared to only $78.5 \%$ of the female adolescents in this level. The age of the adolescent was also found to be significantly correlated to the HGB severity levels $(\mathrm{F}(2,2961)=16.824$ and $p<0.001)$; in the second level $(9-11 \mathrm{~g} / \mathrm{dl})$ the mean age of adolescents $(15.4 \pm 1.8$ years) was higher as compared to the other 2 levels.

Table 9 displays the distribution of ferritin levels of the adolescents which were included in the study (with the criterion of ferritin $<20 \mathrm{ng} /$ $\mathrm{ml})$, according to 3 ferritin severity levels $(<10,10-15$ and $\geq 15 \mathrm{ng} / \mathrm{ml})$, using Chi-Squared test (after Bonferroni correction) and ANOVA tests. 2 factors were found to be significantly correlated with the ferritin levels: the gender and the age of the adolescent; male gender was correlated with higher ferritin levels $(p<0.001)$, with $58.8 \%$ of male adolescents had ferritin levels $>15 \mathrm{ng} / \mathrm{ml}$, as compared to only $43.6 \%$ of females in this group.

In addition, the age of the adolescent was inversely correlated with ferritin levels $(p<0.001)$, with lower ferritin levels at higher ages.

\section{Discussion}

Iron deficiency remains the most common single nutrient deficiency worldwide and a cause of increased morbidity [24]. Iron deficiency anemia, has been well recognized in recent years as a public health problem, by the World Health Organization (WHO) [25].

In addition to infants and young children, a high prevalence of iron deficiency anemia has been reported in adolescents, in whom a marked growth spurt occurs and iron requirements may outstrip absorption [26,27]. Choudhary et al. [28] reported two-thirds of the anemic adolescents in community were suffering from iron deficiency anemia (IDA).

Anemia in adolescence has serious implications for a wide range of outcomes. It causes reduced resistance to infection, impaired physical growth and mental development, and reduced physical fitness, work capacity, and school performance [29-32].
In Israel, which is a multi-cultural developed country, a number of studies have assessed the prevalence of anemia and iron deficiency among those who enlist in combat military service and reflect the bleak situation in this issue among youth in Israel. In a study conducted among soldiers in the border police, Dubnov et al. [33] found a very high incidence of iron deficiency; in $77 \%$ serum ferritin was below 20 $\mathrm{mcg} / \mathrm{dl}$, representing total iron stores depletion. In a study conducted among boys who enlisted in combat service, Novak et al. [34] found iron deficiency among 15\% (defined as ferritin below $25 \mathrm{mcg} / \mathrm{dl}$ ). Among those who enlisted in an elite unit, Merkel et al. [35] found iron deficiency in $18 \%$ of boys (ferritin level below $22 \mathrm{mcg} / \mathrm{dl}$ ). Iron deficiency, and low magnesium levels were also reported in military recruits and in soldiers by Rachmilewitz et al. [36]. Studies conducted among Israeli athletes at various levels of achievement showed a very high incidence of iron deficiency among adolescents and young adults in a variety of athletic fields, such as basketball, soccer, swimming, gymnastics, dance, etc. [37-41].

In the Gulf countries, especially Kuwait, Bahrain, Qatar and Oman the prevalence of anemia, especially iron deficiency anemia, is relatively high. This was observed particularly among preschool children, adolescent girls, and pregnant women, and supported by dietary intake surveys in the Arab Gulf population indicated inadequate intake of iron [42].

In the present study approximately $18 \%$ of the adolescents included in the sample were found to have anemia (compatible with IDA) or iron deficiency, at least, representing a $5.2 \%$ rate from the overall adolescent population in this area, during 2014. This rate resembles the rate reported in other studies $[6,12]$. In addition to anemia, $5.16 \%$ of the adolescents had low ferritin levels $(<20 \mathrm{ng} / \mathrm{mL})$ without anemia, suggesting iron deficiency's prevalence is much higher.

Notably, the sample included only adolescents who performed blood exams during 2014, some routine and some due to complaints, so this number may reflect an over estimation. On the other hand, many adolescents do not pay attention to their medical situation, and don't regularly visit their physician, so this number may be an under estimation of the real prevalence of anemia and iron deficiency among adolescents.

The findings suggested lower levels of HGB and MCV values in non-Jewish adolescents as compared to the Jewish adolescents. This finding may be explained by the dietary preferences of the Arab population in Israel, which contains more cereals, and by the lower 
socio-economic level of the non-Jewish population in this region, in which the low-cost diet, rich in cereals, is preferred, with a low intake of expensive iron containing foods especially cow's meat, fish and poultry.

When examining the age groups, we can see that the average HGB levels were the lowest at the 12.5-15.5 years, and 15.5-17 years age groups, (with values of 11.3 and $11.2 \mathrm{~g} / \mathrm{dL}$, respectively). In addition, the age of the adolescent was inversely correlated with ferritin levels, with lower ferritin levels at higher ages, findings that may reflect higher menstrual blood loss in in girls during this period.

Not surprisingly, more females were included in the study $(85.2 \%)$ as compared to males (14.8\%). In addition, the gender of the adolescent was found to have a significant correlation with the severity of the anemia, females having lower HGB concentrations. Male gender was also correlated with higher ferritin levels, as compared to females.

This observation is consistent with findings of previous reports eluding to the fact that the iron deficiency and anemia in adolescents are caused by increased requirements of nutrients for growth, exacerbated a few years later by the onset of menstruation in girls, but subsides for boys $[27,29,43]$.

Possible explanations for the above observations are the poor dietary habits of the adolescents, the menstrual blood loss, and lack of awareness of iron-deficiency and nutritional status.

It should be remembered that the food consumption habits of the children in general, and adolescents in particular, have changed during the last few decades, toward consumption of too much fat (especially saturated fats), and sweetened beverages [44]. These can induce obesity, which is correlated itself to iron deficiency [45]. Toddlers and adolescents in Israel, as in other Western countries, also drink "energy drinks", which can cause nutritional deficiencies such as vitamin D and iron [46].

\section{Limitations of the study}

- The study included adolescents from one district, of one Health Maintenance Organization (HMO), although from the largest district of the largest HMO in Israel

- It is an observational study, including only adolescents who performed blood tests during 2014, thus the findings do not reflect the actual prevalence of IDA and iron deficiency among adolescents, which may be higher

- The cut-offs for defining IDA and iron deficiency (according to ferritin levels) may be different in different areas and reports, and differ slightly between boys and girl (in some reports the cut-off for boys over 13 years are $13 \mathrm{gr} \%$ ). Although we included participants based also on the ferritin levels, we are aware to the fact that our findings may be an under-estimation of the real prevalence of anemia during this period, and that it may indeed, in part, contribute to the reported gender differences.

- Including patients with thalassemia: Thalassemia is considered the most frequent genetic disease in the world, about $4 \%$ of the world population carries a Thalassemia gene. In northern Israel the mean carrier frequency for $\beta$ Thalassemia is about $2.4 \%$; however, in villages with a primarily Arab population the frequency rises to 9\% [47]. Among the 22310 adolescents performed blood tests, only 27 were found to have a diagnosis of thalassemia, and they were excluded from the study. Nevertheless, there is a possibility that among the adolescents included in the study, some have thalassemia, thus our results reflect an over-estimation of the real prevalence of IDA in this age- group, and may explain some of the differences between Jews and Arabs. When checking the results, most cases with low MCV values, and high RBC values had also low ferritin and iron levels, so even if they are thallasemic, they probably have also iron deficiency.

Overall, when taking in mind these points, some may cause underestimation of the real prevalence of iron deficiency and anemia during adolescence, and some may cause over-estimation of it, thus may "balancing" the results.

Despite the possible limitations, the results of this study surely raise the awareness for this important problem among adolescents.

\section{Conclusions and Recommendations}

Iron deficiency, and IDA are common in adolescents, in whom a marked growth spurt occurs and iron requirements may outstrip absorption, and may have serious implications for a wide range of outcomes. This health problem is completely treatable and reversible, if adequately targeted.

Health educations is highly recommended emphasizing healthy lifestyle, consumption of balanced, nutritious diets, including ironrich food, and decrease the intake of iron absorption's inhibitors like phytate, phosphate, oxalate and tannins, or nutrient with low bioavailability of iron.

Interestingly, intestinal inflammation was recently described as a risk factor for enterocyte iron sequestration. In face of an adolescent with enteric inflammation and IDA, oral iron preparation should be reconsidered, in order to decrease its local toxic effects [48].

In Israel, a routine blood count is recommended only at the age of 9-12 months, in order to evaluate the HGB levels in infancy. We strongly encourage the local health ministry to recommend on performing a routine screening blood count in adolescents, before starting the military service or academic studies, similar to the one performed in infants. If diagnosed with iron deficiency, adequate dosing of ferrous iron is crucial for optimal response.

\section{Conflicts of Interests}

We declare that there was no funding support and no conflicts of interests.

\section{References}

1. WHO (2011) Hemoglobin Concentrations for the Diagnosis of Anemia and Assessment of Severity. Vitamin and Mineral Nutrition Information System 11: 6

2. Orkin S, Fisher D, Ginsburg D, Look A, Lux S, et al. (2015) Nathan and Oski's Hematology and Oncology of Infancy and Childhood 8: 355-365.

3. Zimmermann MB, Hurrell RF (2007) Nutritional iron deficiency. Lancet 370 511-520.

4. Benoist BD, McLean E, Egli I, Cogswell M (2008) Worldwide Prevalence of Anemia 1993-2005.

5. Marcdante K, Kliegman R (2014) Nelson's Essentials of Pediatrics. E-Book with student consult online access. Elsevier Health Sciences 150: 509-523.

6. Whitfield A, Bergmann S, Lazarchick J (2015) Iron Deficiency Anemia Diagnosed in Female Teenagers. J Family Med Community Health 2: 1058.

7. de Andrade Cairo RC, Silva LR, Bustani NC, Marques CD (2014) Iron deficiency anemia in adolescents; A literature review. Nutricion hospitalaria 29: $1240-1249$.

8. Ciesla B (2011) Hematology in Practice (2ndedn). Philadelphia, PA, FA Davis Company. 
Citation: Haimi M, Goldzak-Kunik G, Katz E, Matthias T, Lerner A (2019) Determinants of Iron Deficiency and Anemia among Adolescents in a MultiCultural Country. J Blood Lymph 9: 242. doi: 10.4172/2165-7831.1000242

Page 7 of 7

9. Bhaskaram P (2002) Micronutrient malnutrition, infection, and immunity: an overview. Nutr Rev 60: S40-S45.

10. Gat-Yablonski G, Yackobovitch-Gavan M, Phillip M (2009) Nutrition and growth in pediatrics. Endocrinol Metab Clin North Am 38: 565-586.

11. Thomas D, Chandra J, Sharma S, Jain A, Pemde HK (2015) Determinants of Nutritional Anemia in Adolescents. Indian Pediatr 52: 867-869.

12. Tesfaye M, Yemane T, Adisu W, Asres Y, Gedefaw L (2015) Anemia and iron deficiency among school adolescents: burden, severity, and determinant factors in southwest Ethiopia. Adolesc Health Med Ther 6: 189-196.

13. Haas JD, Brownlie T (2001) Iron deficiency and reduced work capacity: A critical review of the research to determine a causal relationship. J Nutr 131: 676S-690S.

14. Walter T (2003) Effect of iron-deficiency anemia on cognitive skills and neuromaturation in infancy and childhood. Food Nutr Bull 24: S104-S110.

15. Webb TE, Oski FA (1973) Iron deficiency anemia and scholastic achievement in young adolescents. J Pediatr 82: 827-830.

16. Halterman JS, Kaczorowski JM, Aligne CA, Auinger P, Szilagyi PG (2001) Iron deficiency and cognitive achievement among school-aged children and adolescents in the United States. Pediatrics 107: 1381-1386.

17. Ballin A, Berar M, Rubinstein U, Kleter Y, Hershkovitz A, et al. (1992) Iron state of female adolescents. Am J Dis Child 146: 803-805.

18. Bruner AB, Joffe A, Duggan AK, Casella JF, Brandt J (1996) Randomised study of cognitive effects of iron supplementation in non-anaemic iron-deficient adolescent girls. Lancet 348: 992-996.

19. Rowland TW, Deisroth MB, Green GM, Kelleher JF (1988) The effect of iron therapy on the exercise capacity of nonanemic iron-deficient adolescent runners. Am J Dis Child 142: 165-169.

20. Hinton PS, Giordano C, Brownlie T, Haas JD (2000) Iron supplementation improves endurance after training in iron-depleted, nonanemic women. J Appl Physiol 88: 1103-1111.

21. Friedmann B, Weller E, Mairbaurl H, Bärtsch $P$ (2001) Effects of iron repletion on blood volume and performance capacity in young athletes. Med Sci Sports Exerc 33: 741-746

22. Brownlie IV T, Utermohlen V, Hinton PS, Haas JD (2004) Tissue iron deficiency without anemia impairs adaptation in endurance capacity after aerobic training in previously untrained women. Am J Clin Nutr 79: 437-443.

23. Hinton PS, Sinclair LM (2007) Iron supplementation maintains ventilatory threshold and improves energetic efficiency in iron-deficient nonanemic athletes. Eur J Clin Nutr 61: 30-39.

24. Stoskman JA (1987) Iron deficiency anemia: have we come far enough? JAMA 258: $1645-1647$

25. ACC/SCN (2000) Fourth report on the world nutrition situation. Switzerland: United Nations ACC/SCN in collaboration with IFPRI.

26. Wright CM, Reading RF, Halse PC, Watson GJ (1989) Iron deficiency in adolescents. BMJ 298: 1035-1036.

27. Akatsuka A, Aoki $Y$ (1991) Recent trends of anemia in childhood and adolescence and countermeasures. Asian Med L 34: 32-40.

28. Choudhary A, Moses PD, Mony P, Mathai M (2006) Prevalence of anaemia among adolescent girls in the urban slums of Vellore, south India. Trop Doct 36: 167-169.
29. Usha R (2001) Nutritional Anemia. Boca Raton, FL, CRC press, pp: 8-12.

30. Beard JL (2001) Iron biology in immune function, muscle metabolism and neuronal functioning. J Nutr 131: 568S-580S.

31. Halterman JS, Kaczorowski JM, Aligne CA, Auinger P, Szilagyi PG (2001) Iron deficiency and cognitive achievement among school-aged children and adolescents in the United States. Pediatrics 107: 1381-1386.

32. Jain M, Chandra S (2012) Correlation between hematological and cognitive profile of anemic and non-anemic school age girls. Curr Pediatr Res 16: 145-149.

33. Dubnov G, Foldes AJ, Mann G, Magazanik A, Siderer M, et al. (2006) High prevalence of iron deficiency and anemia in female military recruits. Mil Med 171: 866-869.

34. Novack V, Finestone AS, Constantini N, Shpilberg O, Weitzman S, et al. (2007) The prevalence of low hemoglobin values among new infantry recruits and nonlinear relationship between hemoglobin concentration and physical fitness. Am J Hematol 82: 128-133.

35. Merkel D, Huerta M, Grotto I, Blum D, Tal O, et al. (2005) Prevalence of iron deficiency and anemia among strenuously trained adolescents. J Adolesc Health 37: 220-223.

36. Rachmilewitz EA, Blank D, Rohash Z, Polliack A (1986) Thalassemia minor and iron deficiency anemia among Israeli soldiers. Harefuah 110: 437-441.

37. Portal S, Epstein M, Dubnov G (2003) Iron deficiency and anemia in female athletes-causes and risks. Harefuah 142: 698-703.

38. Constantini N, Eliakim A, Zigel L, Yaaron M, Falk B (2000) Iron status of highly active adolescents: Evidence of depleted iron stores in gymnasts. Int J Sport Nutr Exerc Metabol 10: 62-70.

39. Eliakim A, Nemet D, Constantini N (2002) Screening blood tests in members of the Israeli National Olympic team. J Sport Med Phys Fitness 42: 250-255.

40. Dubnov G, Constantini N (2004) Prevalence of iron depletion and anemia in top-level basketball players. Int J Sports Nutr Metabol 14: 30-37.

41. Haimi M, Lerner A (2014) Nutritional deficiencies in the pediatric age group in a multicultural developed country, Israel. World J Clin Cases 2:120-125.

42. Musaiger AO (2002) Iron deficiency anemia among children and pregnant women in the Arab gulf countries: the need for action. Nutrition and Health 16: 161-171.

43. Armstrong PL (1989) Iron deficiency in adolescents. BMJ 298: 499

44. Carvalho NF, Kenney RD, Carrington PH, Hall DE (2001) Severe nutritional deficiencies in toddlers resulting from health food milk alternatives. Pediatrics 107: E46.

45. Pinhas-Hamiel O, Newfield RS, Koren I, Agmon A, Lilos P, et al. (2003) Greater prevalence of iron deficiency in overweight and obese children and adolescents. Int J Obes Relat Metab Disord 27: 416-418.

46. Prais D, Diamond G, Kattan A, Salzberg J, Inbar D (2008) The effect of calcium intake and physical activity on bone quantitative ultrasound measurements in children: a pilot study. J Bone Miner Metab 26: 248-253.

47. Koren A, Zalman L, Palmor H, Ekstein E, Schneour Y, et al. (2002) The prevention programs for beta thalassemia in the Jezreel and Eiron valleys: results of fifteen years' experience. Harefuah 141: 938-943

48. Katz O, Reifen R, Lerner A (2015) $\beta$-Carotene can reverse dysregulation of iron protein in an in vitro model of inflammation. Immunol Res 61: 70-78. 